\title{
Perancangan Aplikasi Manajemen Rantai Pasok Pada Industri Rumah Tangga Puppy Putra Perdana
}

\author{
Trisha Aida Syahputri, Mita Yuanika Sahroni, Yusuf Amrozi \\ UIN Sunan Ampel Surabaya \\ trishaidas@gmail.com,mitaysahroni@gmail.com, yusuf.amrozi@uinsby.ac.id
}

\begin{abstract}
Abstrak
Manajemen rantai pasok merupakan kegiatan yang mengkonversi bahan mentah menjadi barang jadi dan aliran distribusi kepada pelanggan. Tujuan penelitian ini adalah untuk mengetahui proses manajemen rantai pasok pada Puppy Putra Perdana meliputi proses distribusi ke agen dan toko. Metode yang digunakan dalam melakukan penelitian ini adalah analisis deskripsi dengan pendekatan kualitatif. Aplikasi yang dirancang menyajikan informasi bagi pihak internal produsen,agen dan toko berbasis web. Aplikasi ini akan mempermudah komunikasi antara agen dan toko dalam melakukan pemesanan terhadap produk yang ditawarkan oleh Puppy Putra Perdana. Hasil penelitian ini berupa aplikasi manajemen rantai pasok berbasis web yang akan mempermudah Puppy Putra Perdana melakukan transaksi dengan agen maupun dengan toko.
\end{abstract}

Kata kunci: Manajemen rantai pasok,aplikasi,agen,toko

\section{Abstract}

Supply chain management is an activity that converts material into finished goods and distribution flow to customers. The purpose of this study was to determine the supply chain management process in Puppy Putra Perdana including the distribution process to agents and shops. The method used in conducting this research is descriptive analysis with a qualitative approach. The application is designed to provide information for internal manufacturers, agents and web-based stores. This application will facilitate communication between agents and stores in placing an order for products offered by Puppy Putra Perdana. The results of this study are web-based supply chain management applications that will facilitate Puppy Putra Perdana doing transactions with agents and with stores.

Keywords : Supply chain management, applications, agents, shops

\section{PENDAHULUAN}

Dalam era revolusi industri 4.0, sebuah industri seharusnya tidak terlepas dari sebuah teknologi dalam penerapannya untuk menghasilkan sebuah produk dan untuk mengumpulkan informasi terkini. Salah satu kriteria perusahaan industri yang berhasil adalah perusahaan yang mampu menghubungkan lingkungan internal dan eksternal,seperti rantai pasok distribusi yang berada di dalam lingkup ekternal perusahaan. Dalam meningkatkan performa rangkaian proses bisnis dibutuhkan supply chain yang dapat berjalan dengan baik karena perusahaan mampu berkomunikasi dengan baik dengan mitra bisnisnya. Selain meningkatkan efisiensi dan kualitas dari sebuah produk perusahaan juga harus meningkatkan keunggulan kompetitif bagi perusahaan.

Industri menurut Sukirno (1995) adalah perusahaan yang menjalankan kegiatan ekonomi yang tergolong dalam sektor sekunder. Industri juga dapat didefinisikan sebagai suatu kegiatan ekonomi dalam mengolah bahan mentah atau bahan baku menjadi barang setengah jadi kemudian diolah kembali menjadi barang jadi. Penerapan teknologi informasi dan komunikasi pada bidang industri merupakan sebuah kebutuhan untuk pertukaran data dan informasi dengan cepat dan akurat. Kementrian Perindustrian Republik Indonesia memperoleh 
hasil penelitian bahwa pada ekspor Indonesia di tahun 2017, bidang industri menduduki peringkat pertama yaitu sebesar $74,10 \%$ yang kemudian diikuti oleh bidang tambang sebesar $14,39 \%$, migas 9,33\% dan yang terakhir pertanian sebesar 2,18\% [4]. Hal ini mendorong untuk lebih dimajukannya bidang industri di Indonesia dengan mempermudah komunikasi antar peran rantai pasok.

Capaian kinerja pembangunan industri di tahun 2017 menurut Kementrian Perindustrian Republik Indonesia, sektor industri yang memberikan kontribusi terbesar terhadap PDB Tw II 2017 diawali dengan industri pengolahan yaitu sebesar 20,26\% lalu bidang pertanian sebesar $13,92 \%$ dan perdagangan sebesar $13,03 \%$ [4]. Hal ini juga dapat menjadi dorongan untuk lebih memajukannya bidang industri dengan lebih memudahkan teknologi informasi dan komunikasi karena itu juga merupakan kebutuhan utama pada sebuah industri.

Manajemen Rantai Pasok atau dalam bahasa inggris umumnya disebut dengan Supply Chain Management merupakan kegiatan dimana melakukan pengelolaan dari kegiatan yang diawali dengan memperoleh bahan mentah, mentransformasikan bahan mentah tersebut menjadi barang dalam proses dan kemudian menjadi barang jadi, lalu mengirim produk tersebut kepada konsumen. Pada kegiatan manajemen rantai pasok ini biasanya meliputi pengangkutan, pentransferan kredit dan tunai, pemasok, distributor dan bank, utang dan piutang, pergudangan, pemenuhan pesanan dan pembagian informasi mengenai ramalan permintaan, produksi dan kegiatan pengendalian persediaan (Irawan, 2008) [3].

Sebuah industri rumah tangga yang ada di Indonesia lebih banyak didirikan oleh masyarakat menengah ke bawah karena dengan membuat suatu industri rumah tangga dapat meningkatkan ekonomi masyarakat tersebut. Selama ini di masih banyak masyarakat yang belum mempunyai pekerjaan, sehingga pemerintah dapat membuat atau memberikan modal pada masyarakat untuk mendirikan suatu industri rumah tangga, karena dengan adanya industri rumah tangga dapat menjadi wadah kreatifitas masyarakat di berbagai macam bidang, menjadikan masyarakat yang mandiri dan mampu meningkatkan perekonomian masyarakat di sekitar lingkungan industri rumah tangga.

Perusahaan Puppy Putra Perdana merupakan salah satu industri rumah tangga yang bergerak di bidang peralatan bayi. Dalam penerapan supply chain mengalami masalah dalam hal koordinasi antara supplier dan agen belum terjalin begitu baik sehingga proses penambahan nilai dalam rantai pasokan belum berjalan optimal. Sistem pertukaran informasi dan komunikasi menjadi sebuah penghambat jalannya kegiatan produksi sebuah barang. Sering kali terjadi kekurangan bahan baku dalam produksi sebuah produk ketika permintaan konsumen melonjak sehingga membuat sulitnya berkomunikasi antar pelaku. Oleh karena itu kami mengangkat Puppy Putra Perdana sebagai objek penelitian kami untuk meningkatkan sistem Supply Chain Management dari perusahaan ini.

Penelitian ini dibuat untuk mencapai beberapa tujuan, antara lain:

Mempermudah industri rantai pasok, utamanya untuk industri rumah tangga Puppy Putra Perdana dalam memanajemen pasokan dari bahan mentah menjadi bahan jadi kemudian didistribusikannya produk tersebut, Menyediakan aplikasi manajemen rantai pasok industri rumah tangga Puppy Putra Perdana yang dapat dioperasikan di website sehingga lebih memudahkan perusahaan.

\section{METODE}

Metode penelitian atau jenis penelitian sendiri merupakan langkah terpenting untuk memecahkan suatu masalah dengan menguasai metode penelitian yang akan digunakan bukan hanya untuk memecahkan suatu masalah tetapi dapat dikembangkan bidang keilmuannya sehingga dapat bermanfaat bagi masyarakat. Jenis penelitian yang digunakan penelitian ini adalah penelitian deskriptif dengan pendekatan kualitatif.

Penelitian ini dilakukan pada Industri Rumah Tangga Puppy Putra Perdana dengan metode System Development Life Cycle dan model pengembangan untuk merancang dan membuat aplikasi manajemen rantai pasok pada industri rumah tangga Puppy Putra Perdana ini menggunakan model klasik waterfall dengan tahapan-tahapannya yaitu tahap perencanaan, pemodelan, konstruksi dan penyebaran [1] atau 
lebih akrabnya dapat disebut dengan tahapan analisis kebutuhan, desain dan perancangan, implementasi, testing serta pemeliharaan yang kemudian akan dijelaskan setelah ini.

a) Tahap analisis kebutuhan, pada tahap ini penulis menganalisis kebutuhan user untuk mengetahui seluruh kebutuhan stakeholder pada sistem. Analisis kebutuhan user dilakukan dengan melakukan wawancara terhadap stakeholder, observasi langsung yaitu di Perusahaan Industri Rumah Tangga Puppy Putra Perdana sebagai produsen perlengkapan bayi dan dilakukan selama 2 bulan, mulai bulan Oktober 2019 hingga bulan Desember 2019.

Penelitian ini menganalisis data menggunakan teknik wawancara dan observasi. Menurut Sugiyono (2008) "Wawancara adalah percakapan dengan maksud tertentu yang dilkukan oleh dua pihak yaitu pewawancara dan narasumber". Wawancara digunakan untuk memperoleh data yang lebih luas didapat dari jawaban yang diberikan oleh narasumber. Sedangkan observasi merupakan susunan dari berbagai proses biologis dan psikologis, melihat dan mengamati (Sugiyono,2008). Observasi digunakan untuk mendapatkan data secara langsung di lapangan.

Penelitian ini menggunakan analisis data kulaitatif dari Miles and Hubarman (1992) dengan prosedur sebagai berikut : (1) Reduksi data, data yang diperoleh dari lokasi penelitian dikumpulkan, dirangkum dan dipilih menjadi satu pada suatu proposal. (2) Penyajian data yang digunakan dalam penelitian ini adalah dalam bentuk tulisan yang berisi kesimpulan hasil pengamatan untuk memudahkan peneliti melihat gambaran secara keseluruhan dari bagian-bagian tertentu dari penelitiain. (3) Menarik kesimpulan dalam penelitian kualitatif di lakukan secara terus menerus selama proses penelitian berlangsung.

b) Tahap perancangan, pada tahap ini penulis merancang dengan berorientasi objek yang menggunakan UML (Unified Modelling Language). Sistem berorientasi objek terdiri dari objek yang berinteraksi dan mempertahankan keadaan local mereka sendiri dan menyediakan operasi pada keadaan tersebut [2].
Berdasarkan hasil wawancara dan observasi langsung yang telah dilakukan, aplikasi manajemen rantai pasok pada industri rumah tangga memiliki beberapa fungsi utama, yaitu:

1. Dapat melakukan registrasi akun

2. Dapat melakukan login

3. Dapat melihat jumlah stok yang masih tersedia dan yang sudah terjual

4. Dapat memesan produk

5. Dapat menerima pesanan produk

Use case diagram telah dibuat untuk menggambarkan daftar kebutuhan yang telah dirinci sebelumnya.

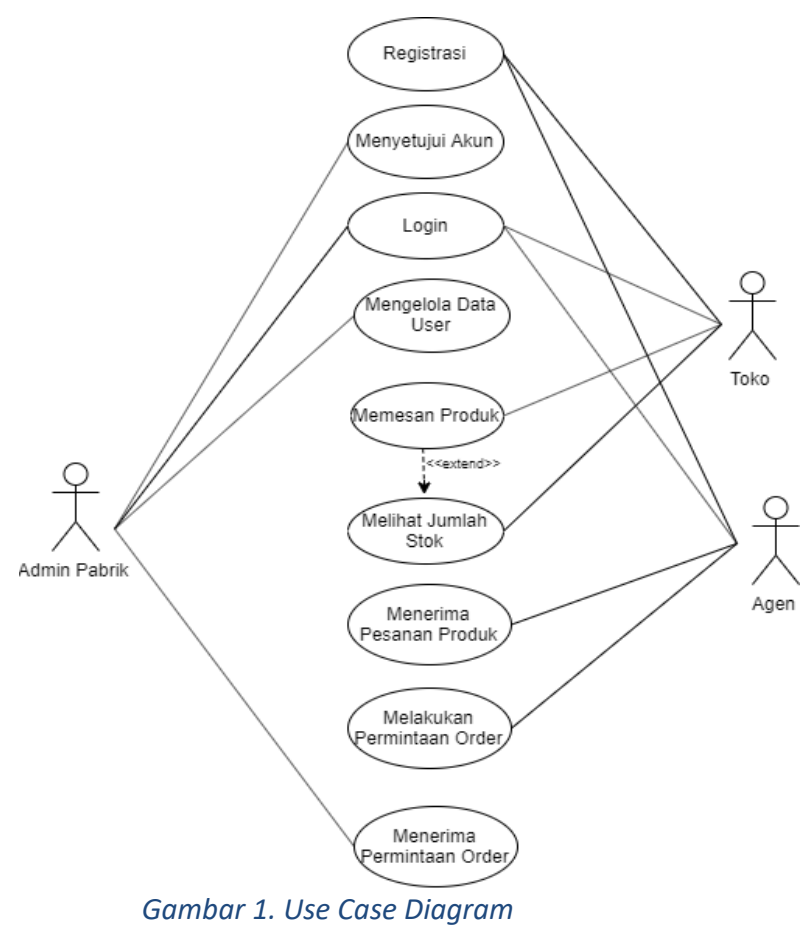

Pada Gbr. 1 didapatkan bahwa aktor dari aplikasi ini dibagi menjadi empat, yaitu Admin Pabrik, Toko, dan Agen. Admin Pabrik disini memiliki tugas yaitu menyetujui akun,mengelola data user dan menerima permintaan order, data user disini maksudnya adalah Toko, Agen dan admin pabrik. Untuk Toko disini memiliki empat tugas, yaitu Registrasi, Login, Melihat Jumlah Stok yang extend pada Memesan Produk. Memesan produk disini maksudnya adalah Toko dapat memesan produk kepada Agen, Toko dapat memesan produk tanpa harus melihat jumlah stok terlebih dahulu.

Lalu untuk Agen, memiliki tugas Registrasi, Login, Melihat Jumlah Stok, Menerima 
Pesanan Produk dan melakukan Permintaan Order. Melakukan permintaan order disini maksudnya adalah Agen dapat melakukan pesanan produk kepada pabrik dan Agen juga dapat menerima pesanan produk dari Toko.

Sedangkan untuk admin pabrik hanya dapat melakukan registrasi, login dan menerima permintaan order saja. Menerima permintaan order disini merupakan pesanan dari Agen.

c) Tahap implementasi, pada tahap ini penulis menggunakan bahasa pemrograman PHP dan javascript, peneliti menggunakan database mysql dan framework Codelgniter dalam membangun aplikasi ini. Penulis juga dibantu dengan notepad++ dan xampp dalam tahap membangun aplikasi.

d) Tahap pengujian, pada tahap ini penulis menguji atau mencoba aplikasi yang telah dibuat guna apabila terdapat kesalahan dapat diketahui dan dapat diperbaiki.

\section{HASIL}

Pada bab ini akan memaparkan tentang hasil dan pembahasan dari penelitian yang telah dilakukan. Implementasi dari Perancangan Aplikasi Manajemen Rantai Pasok Industri Rumah Tangga Puppy Putra Perdana ini menggunakan model MVC (Model View Controller) dengan menggunakan framework Codelgniter. Terdapat 3 akses untuk aplikasi ini, yaitu Pabrik, Agen dan Toko.

\section{Tampilan Login}

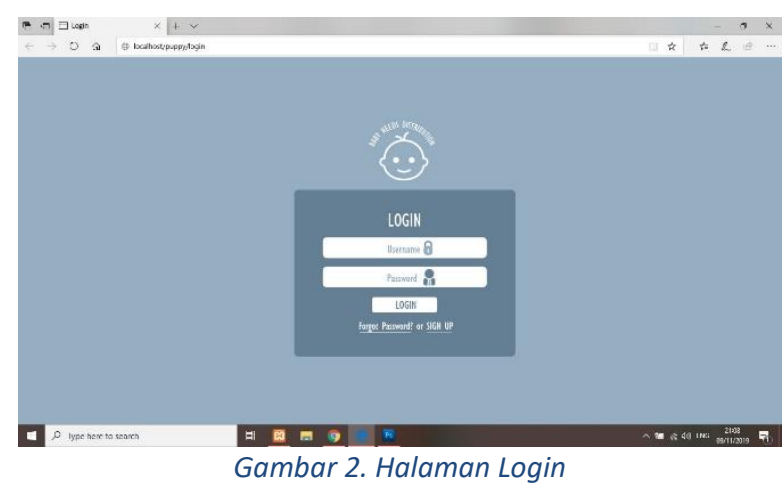

Pada Gbr. 2 menjelaskan halaman utama ketika mengakses aplikasi tersebut. Ketika pengguna membuka aplikasi tersebut, hal pertama yang ditampilkan adalah menu login. Pada tampilan login, terdapat 3 hak akses, yaitu Pabrik, Agen dan Toko. Pengguna membutuhkan username dan password untuk login, username telah diinput ketika registrasi akun. Apabila lupa dengan passwordnya, dapat menekan tombol "Forgot Password?" dan ketika belum memiliki akun, dapat menekan tombol "Sign Up".

\section{Tampilan Pabrik Menerima Permintaan Order}

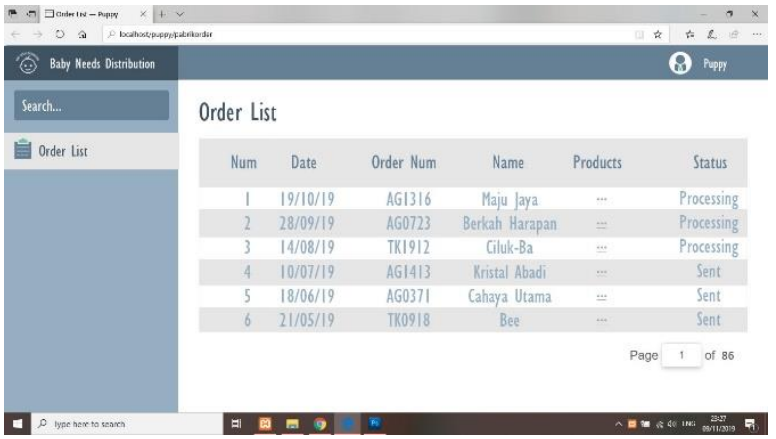

Gambar 3. Pabrik Menerima Permintaan Order

Gbr. 3 merupakan tampilan untuk Pabrik ketika menerima pesanan. Pada tabel terdapat kolom Num, Date, Order Num, Name, Products dan Status. Date disini merupakan tanggal dimana pemesanan produk dilakukan. Order num disini maksudnya adalah nomer oder, setiap pesanan memiliki nomor order tersendiri. Name disini merupakan nama toko atau agen yang memesan produk pada pabrik, Products adalah daftar pesanan produk tersebut dan status merupakan status dari barang, apakah barang sudah dikirim atau sedang masa pembuatan.

\section{Tampilan Agen Melakukan Permintaan Order}

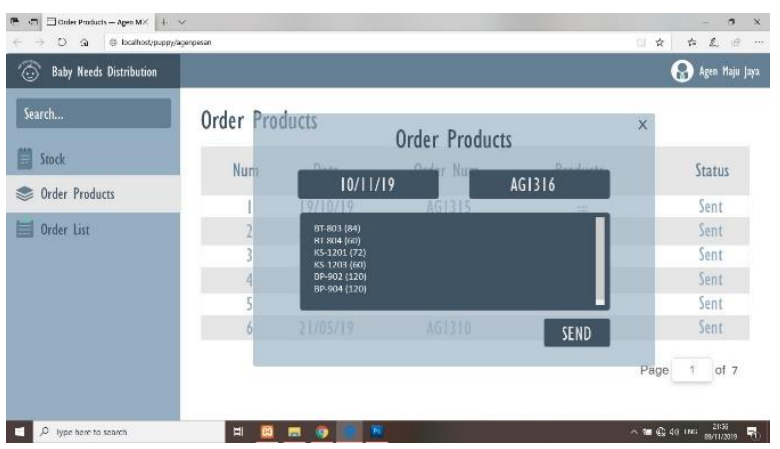

Gambar 4. Agen Melakukan Permintaan Order

Pada Gbr. 4, mendeskripsikan bahwa pada menu melakukan pesanan produk untuk agen, disana terdapat kotak tanggal, kotak nomor pesanan dan kotak daftar barang yang akan dipesan. Untuk tanggal dan kode toko ditullis dengan otomatis dan tidak dapat dirubah, 
pengguna hanya mengisi bagian daftar barang yang akan dipesan kemudian menekan tombol send, apabila telah ditekan tombol send, maka pesanan akan masuk pada tabel Order Products seperti berikut:

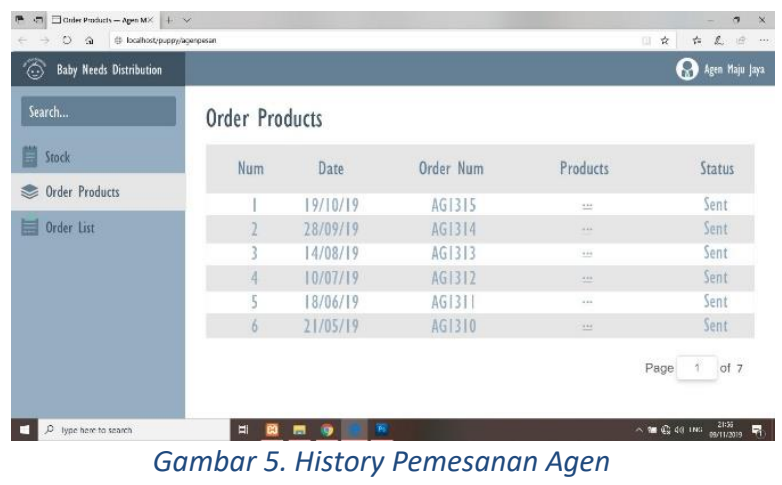

Disana terdapat tabel Num, Date, Order Num, Products dan Status.

\section{Tampilan Stok Yang Tersedia Pada Toko}

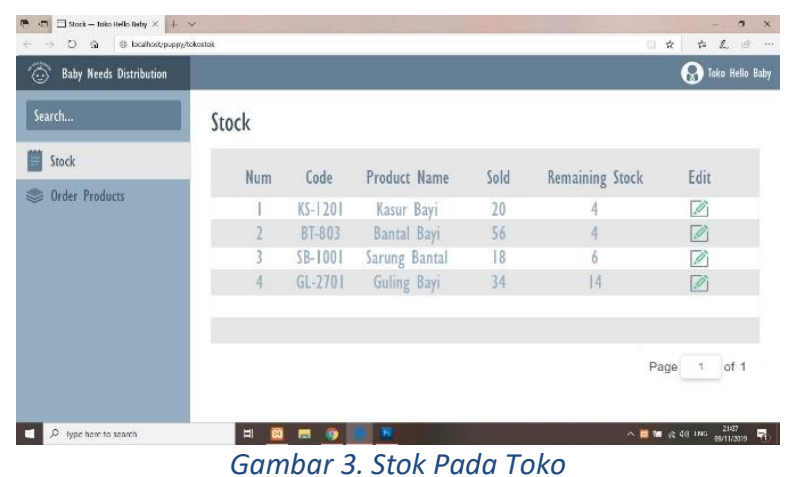

Gbr. 6 di atas merupakan tampilan untuk Stok pada toko, disana terdapat kolom num, code, product name, sold, remaining stock dan edit. Code disini merupakan kode dari tiap barang, setiap barang memiliki kode barang masingmasing. Sold disini merupakan jumlah barang yang telah terjual, Remaining Stock merupakan jumlah barang yang masih tersedia pada toko. Edit disini memiliki fungsi untuk mengubah data yang ada, seperti mengubah data sold dan remaining stock.

\section{KESIMPULAN}

Kesimpulan dari penelitian ini adalah :

1. Industri rumah tangga Puppy Putra Perdana dapat menjalankan strategi bisnis manajemen rantai pasok secara online dimana proses bisnis yang sudah berjalan secara konvensional akan dirubah ke dalam bentuk online melalui penggunaan aplikasi web.

2. Aplikasi ini dibangun untuk mempermudah komunikasi atau hubungan antara agen dan toko dalam melakukan transaksi bisnis dengan produsen.

3. Pendistribusian perlengkapan bayi dari Puppy Putra Perdana dilakukan terpusat dimana pasokan yang diterima agen dari produsen akan di distribusikan lagi ke toko-toko peralatan bayi yang kemudian akan sampai ke konsumen.

\section{DAFTAR PUSTAKA}

[1]. Pressman, Roger S. dan Maxim, Bruce R. "Software Engineering A Practitioner's Approach". 2015. Mc Graw Hill Education.

[2]. Sommerville, lan. "Software Engineering". 2011. Pearson.

[3]. Irawan, Agustinus Purna. "Buku Ajar Manajemen Rantai Pasokan". 2008. Fakultas Teknik Universitas Tarumanegara.

[4]. https://kemenperin.go.id/gpr (diakses Sabtu, 19/10/2019).

[5]. Lanier, Danny. William F. Wempe, dan Morgan Swink. "Supply Chain Power And Real Earnings Management: Stock Market Perceptions, Financial Performance Effects, And Implications For Suppliers". 2018. Journal of Supply Chain Management. URL: https://onlinelibrary.wiley.com/doi/epdf 110.1111/jscm.12186.

[6]. Manambing, Melva F. Petrus Tumade, dan Jacky S. B. Sumarauw. "Analisis Perencanaan Supply Chain Management (SCM) Pada PT. Sinar Galesong Pratama". 2014. Jurnal Emba: Jurnal Riset Ekonomi, Manajemen, Bisnis Dan Akuntansi.

URL: https://ejournal.unsrat.ac.id/index.php/ emba/article/view/4933/4449.

[7]. Diana, Desra Isma. Rochadi Tawaf, Maman Paturochman. "Analysis Of Supply Chain Management Food Industries Sausage From Producent To Consument In Bandung (The Case Study at PT Kemfood Bandung)". 2016. URL: http://jurnal.unpad.ac.id/ejournal/articl e/view/8580/3970. 
[8]. Vistasusiyanti, Paulus Kindangen, Indrie Debbie Palandeng. "Analysis Supply Chain Management (SCM) Spring Bed At PT. Massindo Sinar Pratama Kota Manado". 2017. Jurnal Emba: Jurnal Riset Ekonomi, Manajemen, Bisnis Dan Akuntansi.

URL:

https://ejournal.unsrat.ac.id/index.php/ emba/article/view/16013/15521.

[9]. Rudy, dkk. "Analisis Dan Perancangan ESCM. (Studi Kasus: PT. Multi Megah Mandiri)". 2008. Seminar Nasional Informatika 2008 (semnasIF 2008). URL: https://media.neliti.com/media/publicat ions/175194-ID-analisis-dan-

perancangan-e-scm-studi-kas.pdf.

[10]. Sharma, Ashwini. Dixit Garg, Ashish Agarwal. "Quality Management In Supply Chains: The Literature Review." 2012. International Journal for Quality Research. URL: http://ijar.net/journal/v6-n3/3.pdf. 